\title{
Naturecultures: Introduction
}

\section{Emily Potter and Gay Hawkins}

This collection of essays, grouped under the theme of 'Naturecultures', offers a range of approaches to a common concern: to decentre humans from our ontological, ethical-political and cultural stories. The imperative to think about non-human matter in ethical-political terms is fuelled by the environmental calamities currently facing the Earth. But it is inspired by the recognition that humans and non-humans are intimately bound in ways that put into question some of the fundamental precepts of western thought.

The term 'natureculture' indicates the starting point for this project. Enlightenment logic positioned the thinking human subject at the centre of the world, the master not only of reason but of agency too. Culture, the realm of human meaning and creativity, was set out as distinct from nature, the domain of non-human (or at least, non-human authored) matter and life. Ethical-political theory, as well as political institutions, developed along these philosophic lines.

However in the multiple milieux of everyday life, humans and non-humans have always been caught up with each other in ways that make a nature/culture binary impossible to sustain - something that many non-western cultures have long acknowledged. As Stephen Muecke reminds us, 'we have only ever managed to philosophise with the help of things: the turning stars, apples which fall, turtles and hares, rivers and gods... They all have a part to play, forming collectivities which have to decide who can live with what and how'.

These essays think through specific things or situations - the life of the plastic bag, new media art, the ecological footprint, and managing urban water demand - and critical concepts such as agency, ontology, ecology, materiality, co-constructionism and representation, to explore this interactivity of human and non-human life and its implications for fundamental questions of who we are; how we know and how what we know comes to be. The purpose, however, is not to assert the capacities of the non-human at the expense of the human, or privilege one form of matter or life over another - quite the contrary; it is, in Kay Anderson's words, to ask 'how we might live in our more-than-human worlds' (xviii).

This collection is an outcome of a collaborative process that sought to think through these questions in conversation. All the essays originate from the Cultural Studies Association of Australia Conference held in Adelaide in December 2007, where a group of senior academics, early-career researchers and postgraduate students were drawn together by a common interest in natureculture thinking. 
A workshop held in May 2008 provided an opportunity for us all to further develop these papers around the table; a final process of one-on-one reviewing amongst the group pushed the essays to their next iteration.

It is worth recounting this history, not just for the background it provides to the collection, but for the contrasting model it offers to the solitary critic privileged in the Enlightenment tradition. A world composed of and through (re)arrangements of matter and energy, both human and non-human, requires not just new ways of thinking, but different ways of working, too. Not all the essays developed through these conversations are published here: other contributions dealt with technology transfer in international development aid projects; dust mites and human respiratory problems; the use of pedometers as a technical reconstitution of the everyday activity of walking; and the technical and social messages encoded in hotel security swipe-cards. The influence of these papers remains, however, in the texture of the others published here, as well as in the ongoing conversations they have inspired. We would like to acknowledge the ARC-funded Cultural Research Network, especially the Cultural Histories and Cultural Geographies Node, for its support of this natureculture initiative.

Emily Potter is a Research Fellow in the Institute for Citizenship and Globalisation, Deakin University. Her areas of research interest include creative research, cultural theory and environmental practice. She is the co-editor of Fresh Water: New Perspectives on Water in Australia (MUP, 2007), and her academic articles have appeared in both Australian and international journals including Antipodes, Media International Australia, Cultural Studies Review and Continuum.

Gay Hawkins is a Professor of media and social theory in the School of English, Media and Performing Arts at UNSW. Her latest books are The Ethics of Waste: How We Relate to Rubbish (2006) and, with Ien Ang and Lamia Dabboussy, The SBS Story: The Challenge of Cultural Diversity (2008). She is currently undertaking a large ARC project, 'From the Tap to the Bottle: The Social and Material Life of Bottled Water'. 


\section{Works Cited}

Anderson, Kay and Bruce P. Braun. 'Introduction.' Environment: Critical Essays in Human Geography. Ed. Kay Anderson and Bruce P. Braun. Aldershot: Ashgate, 2008.

Muecke, Stephen. 'Cultural Science? Radical Contingency, Radical Empiricism and the Future Habitat of the Humanities.' Cultural Studies, forthcoming 2009. 